\title{
Selective Removal of Toxic Ions from Water/ Wastewater: Using a Novel Surfactant
}

Citation: M. Ziaee, M. Taseidifar, R.M. Pashley, B.W. Ninham (2020) Selective Removal of Toxic Ions from Water/ Wastewater: Using a Novel Surfactant. Substantia 4(2) Suppl.: 79-88. doi: 10.36253/Substantia-830

Copyright: (c) 2020 M. Ziaee, M. Taseidifar, R.M. Pashley, B.W. Ninham. This is an open access, peer-reviewed article published by Firenze University Press (http://www.fupress.com/substantia) and distributed under the terms of the Creative Commons Attribution License, which permits unrestricted use, distribution, and reproduction in any medium, provided the original author and source are credited.

Data Availability Statement: All relevant data are within the paper and its Supporting Information files.

Competing Interests: The Author(s) declare(s) no conflict of interest.

\author{
Mohammad Ziaee ${ }^{1}$, Mojtaba Taseidifar ${ }^{1}$, Richard M. Pashley ${ }^{1}$, Barry \\ W. NINHAM ${ }^{2, *}$ \\ ${ }^{1}$ School of Science, University of New South Wales, Northcott Drive, Canberra, Australia \\ ${ }^{2}$ Department of Applied Mathematics, Research School of Physical Sciences, The Austral- \\ ian National University, Canberra, Australia \\ *Corresponding author: barry.ninham@anu.edu.au
}

\begin{abstract}
Pollution of drinking water by toxic heavy-metal ions is a matter of concern worldwide. These ions occur naturally, and also from environmental spills, radioactive wastes and other industrial waste. Arsenic and lead are typical examples. A novel green surfactant, purpose designed, and environmentally friendly is shown to be extremely effective and specific for heavy metal ion removal. This is a considerable step forward on previous technologies. Surfactants have been used universally to remove organic and inorganic contaminants from water. But little selectivity has been achieved. After usage, the residual surfactants are discharged into surface waters or sewage systems. This causes environmental pollution. In this review, three surfactants from different classes (novel green surfactant, synthetic chemical surfactant and biosurfactant) are compared in terms of their efficiency in flotation, removal of different heavy-metal ions, biodegradability, and toxicity level, including their advantages and disadvantages.
\end{abstract}

Keywords: ion flotation, green surfactant, chemical synthetic surfactant, biosurfactant, water treatment, toxic heavy metals.

\section{INTRODUCTION}

Low but toxic amounts of heavy metal ions like arsenic occur naturally in drinking water. It is a long-standing problem. It affects millions of people. There has been little progress towards its solution. Similar environmental issues of increasing concern are: wastewater from mining operations, battery and electronic manufacturing, the paper industry, radioactive waste disposal, which all pose massive challenges. The discharge of such waste waters into rivers and lakes affect aquifers, discharge into the ocean and can cause serious problems to marine life and to public health., ${ }^{1,2}$

Heavy metals such as chromium $(\mathrm{Cr})$, cobalt $(\mathrm{Co})$, lead $(\mathrm{Pb})$, cadmium $(\mathrm{Cd})$, mercury $(\mathrm{Hg})$, nickel $(\mathrm{Ni})$, zinc $(\mathrm{Zn})$ and copper $(\mathrm{Cu})$ are not biodegradable and they can accumulate in human tissues. Cobalt and chromium are a big problem with joint replacement surgery, and horse racing! Another 
example: although zinc is essential for normal function of both eukaryotic and prokaryotic cells and other different human tissues, excessive amounts of zinc cause skin irritation and vomiting. ${ }^{3}$ Another ion, copper is an important element in human metabolism; however, excessive ingestion of copper can lead to spasms, vomiting, and even death. ${ }^{4}$

Heavy-metal ions like radioactive strontium and radium in low concentration are among the most damaging in nuclear waste. So new techniques that allow removal, and especially selective removal of contaminating heavy metal ions, wherever they occur, is a matter of highest importance. The urgent need for separation technologies for rare earth metals for the computer industry reinforce this.

In the medical field, a large amount of research has focused on establishing critical heavy metal levels in the human body. For instance, nickel, lead, mercury, cadmium, and chromium can be carcinogenic and cause serious problems for normal human organ function..$^{5-7}$

The existence of heavy metal ions in industrial wastewater, a matter of global concern, has led to stricter environmental regulations. Much research on the removal of heavy metal ions from water has been aimed at several different methods: membrane technology, adsorption, ion exchange, chemical precipitation, and flotation. Of these, flotation is a technique of much promise. This method is able to remove heavy metal ions using bubbles and a 'collector' in the aqueous phase. In the context of minerals beneficiation, collectors are usually surfactant molecules. They are used in froth flotation of particulates, metal rich minerals that attach to surfactant coated air bubbles. They typically leave unwanted substances like silica and clays behind in the flotation process.

There are several processes that use this technique: froth flotation, dissolved air flotation, precipitation flotation, and ion flotation that are well described in references. ${ }^{8,9}$

Ion flotation derives from the mineral separation industry. It is a technique also capable of removing organic and inorganic contaminants either in anionic or cationic forms from wastewaters. ${ }^{10}$ Currently, ion flotation is in use for the recovery of precious metals, ion separation, and wastewater treatment because of its low energy consumption, inexpensive ancillary devices, flexibility, and a negligible amount of sludge. ${ }^{11,12}$ A simple schematic of a laboratory scale ion flotation process is depicted in Figure 1 and shown in the graphical abstract.

The conventional picture of how froth flotation separation of mineral particles works has it that surfactants adsorb onto finely ground hydrophilic mineral particles, selectively converting the required mineral to possess a

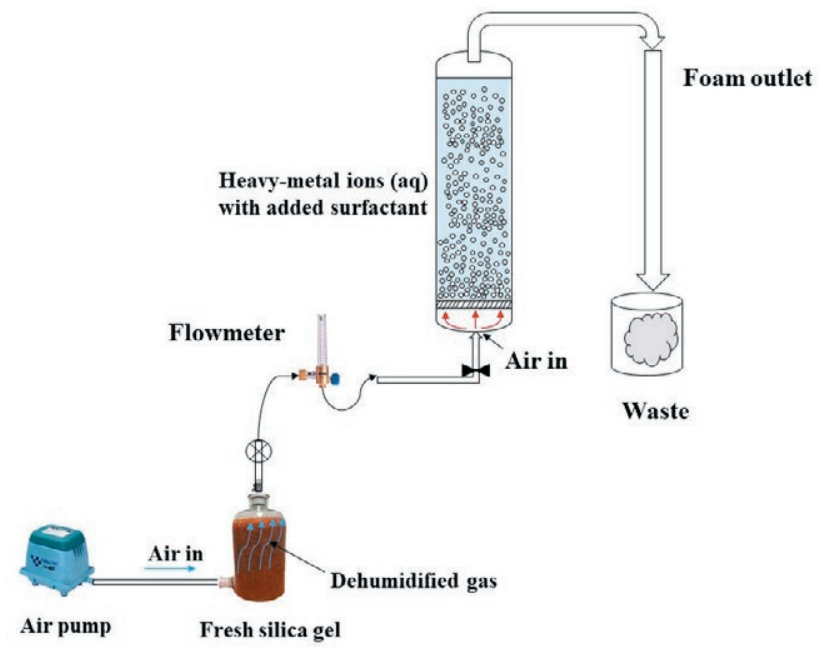

Figure 1. Schematic diagram of the column setup for ion flotation process.

hydrophobic surface. The continuous flow of a high density of bubbles captures the coated hydrophobic particles and carries them off into the collected foam. Naturally hydrophobic particles, such as talc and some mineral sulphides, float naturally, whereas most minerals are hydrophilic and will not float unless coated with an adsorbed layer of surfactant. The selective and controlled hydrophobicity of the mineral particles in a mixture, facilitates the successful selectivity of the froth flotation separation process.

Our interest is in ion flotation for which the simplest explanation is different but closely related to froth flotation. The important process is that surfactants adsorb to bubbles below the $\mathrm{CMC}$, to provide a monolayer to which the heavy metal ions to be collected adsorb specifically and as the bubbles rise, the surfactant-ion complex can be collected in the froth. At the same time, ions in solution may selectively bind to the surfactant head-group(s) and then be adsorbed at the bubble surface. Whichever process dominates, it works and our aim here is to make the process as specific as possible. In this study, the effectiveness of a novel kind of surfactant designed for specificity in the removal of heavy metal ions has been explored and compared with two other standard surfactants.

\section{GREEN SYNTHETIC SURFACTANTS. HINTS FROM BIOLOGY}

The promise of flotation techniques has not been matched by expectation so far. The goal of selectivity, of specificity, in harvesting heavy metal ions has remained 
an Elusive Eldorado. Taking a lesson from biology, from enzymes, we have synthesised novel surfactants that go some way to achieving improved specificity. There are double pluses in this. The most widely used surfactants are made from petroleum compounds. These surfactants are made by a wide range of industries, which themselves produce toxic products for the environment. Remediation methods of these surfactants include ozonation, UV radiation and catalyst-coupled auto-oxidations, which are of economic concern. In addition, the levels of $\mathrm{CO}_{2}$ liberated by petrochemical processes for the synthesis of the surfactants was found to be as high as $37 \%$ in the EU. Further, cationic surfactants with quaternary ammonium and pyridinium headgroups widely used in many household and pharmaceutical/ medical applications are potent immunosuppressants (see section 3 below).

These difficulties have led to the idea of going green, that is, through the search for a new class of surfactants which are to be obtained from raw renewable materials. ${ }^{13}$ Environmentally friendly, or "Green Surfactants" can be obtained from natural and renewable ingredients. They should be biodegradable with low toxicity. There are evolving stricter environmental regulations due to increasing concern about traditional surfactants which create health and environmental /water pollution issues. Our goal in this search for green surfactants that are ion specific is made easier in that Nature has already shown the way. The shape, folding and hydrophobicity that determines structure and function of proteins and enzymes all depend on binding of specific ions to sites with specific dispersion forces and hydration compatibility. There are myriad examples of active sites within enzymes that bind specific, usually divalent, ions that can serve as guides to templates that suggest prototypes for novel synthesised surfactant head groups.

\subsection{L-cysteine an exemplar}

L-cysteine is an amino acid that is biosynthesised in the human body, mostly in keratin-rich tissues, such as nails, hair, and skin which have the highest level of cysteine. ${ }^{14}$ Different cysteine-based green surfactants with suitable hydrocarbon chain lengths can be synthesized by reacting octanoyl chloride and dodecanoyl chloride with cysteine. ${ }^{15,16}$

Such surfactants have many useful properties. They are edible! So, their potential as a soap in industry is immense. For our present problem of heavy metal contamination, then if a slight amount of this surfactant remains in treated water after a flotation process, it will not be harmful for human beings compared to tradition-

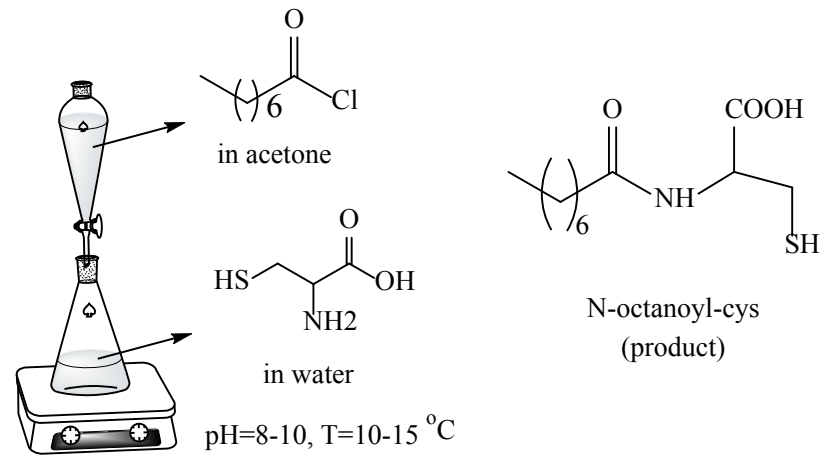

Figure 2. Schematic for the synthesis of octanoyl-cysteine surfactant from octanoyl chloride, in acetone, and L-cysteine in water. $^{16}$

al chemical synthetic surfactants. It might even put hair on our chests!

\subsection{Reaction synthesis}

Below is the standard reaction synthesis method which can be used to obtain different cysteine-based surfactants. ${ }^{15,16}$ The obtained surfactant was recrystallised in a mixture of ethanol:water ( $\mathrm{V}: \mathrm{V}$ 50:50) twice before using in the ion flotation experiments.

\subsection{Green Surfactant Properties}

These surfactants can be naturally decomposed by enzymes known as peptidases and proteases, a process that takes place in the intestine. The process produces octanoic acid and cysteine, which are both natural and have health benefits. Octanoic acid is an organic carboxylic acid, which is found naturally in the milk of various mammals and is a minor component of kernel oil, palm, and coconut oil. Octanoic acid (caprylic acid), can also be taken as a dietary supplement due to its anti-inflammatory and antimicrobial properties. As a consequence, both of the products of this decomposition reaction are compatible with the human body.

\subsection{An application to arsenic removal}

Cysteine-based surfactants with different chain lengths were developed and used for removal of low level of arsenic from drinking water. ${ }^{16}$ Single chain octanoylcysteine (s-octanoyl-cys) and single chain dodecanoylcysteine (s-dodecanoyl-cys) have been applied as the collectors in a single stage batch ion flotation process. The 
Table 1. Ion flotation results for the removal of arsenic ions (5 $\mathrm{mg} / \mathrm{L}$ or $\mathrm{ppm})$ at $\mathrm{pH}=8$ using different cysteine-based surfactants (reproduced from $\left.{ }^{15}\right)$. C(surfactant $)=0.01 \mathrm{M}$.

\begin{tabular}{lcccc}
\hline Surfactant & $\begin{array}{c}\text { As (ppm) } \\
\text { after 30 } \\
\text { mins }\end{array}$ & $\begin{array}{c}\text { Removal } \\
(\%) \text { after } \\
30 \text { mins }\end{array}$ & $\begin{array}{c}\text { As (ppm) } \\
\text { after 60 } \\
\text { mins }\end{array}$ & $\begin{array}{c}\text { Removal } \\
(\%) \text { after } \\
60 \text { mins }\end{array}$ \\
\hline $\begin{array}{l}\text { S-Octanoyl-cys 1 } \\
\text { st }\end{array}$ & 0.442 & 91.2 & 0.120 & 97.6 \\
$\begin{array}{l}\text { S-Octanstallized } \\
\text { crystallized }\end{array}$ & 0.135 & 97.3 & 0.025 & 99.5 \\
$\begin{array}{l}\text { S-Dodecanoyl-cys 2 } 2^{\text {nd }} \\
\text { crystallized }\end{array}$ & 3.310 & 33.8 & 2.34 & 53.2 \\
\hline
\end{tabular}

results obtained are given in Table 1 . The single-chain octanoyl-cysteine surfactant was found to have a relatively high CMC value of $0.1 \mathrm{~mol} / \mathrm{L}$ and showed significant foaming ability. The corresponding values for dodecanoyl cysteine surfactant were found to be $0.009 \mathrm{~mol} / \mathrm{L}$. The dodecanoyl-cysteine surfactant, with the lowest $\mathrm{CMC}$ value, also showed the lowest solubility in water and the weakest foaming ability.

It is necessary to avoid forming micelles, in which the surfactant spontaneously forms surfactant aggregates that make the flotation process less efficient. During the ion flotation experiments here, the initial concentrations of these surfactants were used at about 0.1 of their $\mathrm{CMC}(\mathrm{s})$, i.e. at levels of $0.01 \mathrm{M}$ and $0.0009 \mathrm{M}$, respectively.

These experiments were performed at $\mathrm{pH}=8$ (using $\mathrm{NaOH} 10 \% \mathrm{w} / \mathrm{w}$ ), and an initial concentration of 5 $\mathrm{mg} / \mathrm{L}$ (ppm) for arsenic, As (V) ions. Based on Table 1, S-octanoyl-cys shows superior affinity with As (V) rather than S-dodecanoyl-cys surfactant. As a consequence, after 60 minutes ion flotation, S-octanoyl-cys was able to remove $97.6 \%$ of As (V), while S-dodecanoyl-cys was capable of removing only $53 \%$ of the initial arsenic ions from solution.

Most of the research on the binding process of heavy metals to cysteine is limited to computation- al studies, however there are few experimental studies based on NMR analyses. It has been reported ${ }^{17}$ that three cysteine molecules are needed to make the As $(\mathrm{Cys})_{3}$ complex, coordinated with thiolates. This coordination, resulting in a pyramid trigonal site, makes the interaction between As (III) (arsenite) and sulfhydryl in cysteine group more stabilized; and this demonstrates a possible cause of the toxicity mechanism for arsenic in causing structural distortion of cysteine-based biopolymers. ${ }^{18}$ Binding of $\mathrm{Cd}$ ions with cysteine was also studied using ${ }^{113} \mathrm{Cd}$ NMR spectrum, which displayed 9 resonances where 8 of them were at the range of 600 $700 \mathrm{ppm}$, related to S-thiolate coordination for the Cd ions. While one resonance occurred at 516ppm, which is destabilised and can be interrupted. This resonance relates to C-terminal cluster of $\mathrm{Cd}$ ions to the cysteine molecule. ${ }^{19}$

\subsection{The effects of the input gas type}

The effect of different gases on the efficiency of heavy metal ion removal in the ion flotation process was also examined..$^{15}$ Pure nitrogen and dry air were introduced separately to the bubble column to produce bubbles with an average of about $2 \mathrm{~mm}$ diameter. The results presented in Table 2 show that air gas was slightly better for ion flotation than nitrogen, removing $99.9 \%$ of the arsenic compared with $99.4 \%$ for nitrogen (see Table 2). Mercury was found to have the highest removal rate in the presence of nitrogen gas, at $99.9 \%$; with air, $99.6 \%$ was removed. Table 2 indicates the results of removing arsenic, lead, and mercury from water using S-octanoylcys as the collector and $\mathrm{N}_{2}$ and air as the inlet gases to produce bubbles.

The results presented in Table 2, illustrate that the green S-octanoyl-cys surfactant is entirely able to remove lead, mercury, and arsenic ions from aqueous solutions, at levels more than $99 \%$. According to the Table, this green surfactant almost gives the same efficiency either using

Table 2. Flotation results for of $5 \mathrm{mg} / \mathrm{L}(\mathrm{ppm})$ of different heavy-metals ions using s-octanoyl-cys, $\mathrm{C}($ surfactant $)=0.01 \mathrm{M}$ and $\mathrm{pH}=8$. (Reproduced from ${ }^{15}$ ).

\begin{tabular}{|c|c|c|c|c|c|c|}
\hline Contaminant & Inlet gas & $\begin{array}{c}\text { As }(\mathrm{ppm}) \text { after } 30 \\
\text { mins }\end{array}$ & $\begin{array}{l}\text { Removal (\%) after } \\
30 \text { mins }\end{array}$ & $\begin{array}{c}\text { As }(\mathrm{ppm}) \text { after } 60 \\
\text { mins }\end{array}$ & $\begin{array}{l}\text { Removal (\%) after } \\
60 \text { mins }\end{array}$ & Ref. \\
\hline Lead & air & 0.399 & 92.0 & 0.0467 & 99.1 & 15 \\
\hline Lead & nitrogen & 0.257 & 94.9 & 0.032 & 99.4 & 15 \\
\hline Mercury & air & 0.024 & 99.5 & 0.020 & 99.6 & 15 \\
\hline Mercury & nitrogen & 0.022 & 99.6 & 0.002 & 99.9 & 15 \\
\hline Arsenic & air & 0.137 & 97.3 & 0.006 & 99.9 & 20 \\
\hline Arsenic & nitrogen & 0.032 & 99.4 & 0.029 & 99.4 & 20 \\
\hline
\end{tabular}


air or nitrogen gas. This high efficiency is remarkable and suggests that the process could be used to treat water contaminated with heavy metal ions like arsenic (As), which is a naturally occuring toxic element and human carcinogen in countries such as Bangladesh, India, Brazil and China. Its concentration has often been increased in ground water due to industrial waste from mining, metallurgy and also the use of toxic substances such as pesticides, in some parts of the world, leading to even greater levels of contamination of ground water and crops. ${ }^{21,22}$

From these results, it appears that air could be used instead of the relatively expensive pure nitrogen gas to reduce the operation costs of a commercial ion flotation plant. It is notable that according to World Health Organisation (WHO), the acceptable level of heavymetal ions in drinking water is less than $0.5 \mathrm{mg} / \mathrm{L}$. After 60 minutes ion flotation using the green S-octanoyl-cys surfactant, the concentrations of lead, mercury, and arsenic ions in water are $0.046,0.02$, and $0.029 \mathrm{mg} / \mathrm{L}$, respectively, which are 10 to 25 times lower than the WHO standard level.

Following the excellent results for removal of heavy metal ions by using S-octanoyl-cys as the collector, a wide range of heavy metals were examined in a single batch stage flotation process. Removal of eight common heavy metals: cadmium, chromium, strontium, calcium, gold, mercury, lead, and arsenic were determined after sixty minutes bubbling. ${ }^{12,15,20}$ The initial concentration of each single metal ion was $5 \mathrm{mg} / \mathrm{L}$ and the initial concentration of used S-octanoyl-cys surfactant was adjusted to $0.01 \mathrm{M}$. These experiments were carried out at $\mathrm{pH}=8$ (using $\mathrm{NaOH}$ 10\% w/w) and the results obtained for each single heavy-metal ion are reported in Table 3.

As the Table shows, there is an excellent affinity between the surfactant and various metal ions in the aqueous solutions. This green biodegradable surfactant

Table 3. Ion flotation results of different single heavy metals in aqueous solution using $\mathrm{S}$-octanoyl-cys $(\mathrm{C}($ surfactant, initial $)=$ $0.01 \mathrm{M}, \mathrm{C}$ (heavy metal ion, initial) $=5 \mathrm{mg} / \mathrm{L}(\mathrm{ppm})$, and $\mathrm{pH}=8)$. (Reproduced from ${ }^{12,20}$ ).

\begin{tabular}{ccccc}
\hline $\begin{array}{c}\text { Single } \\
\text { pollutant }\end{array}$ & $\begin{array}{c}\mathrm{C}(\mathrm{ppm}) \\
\text { after 30 min }\end{array}$ & $\begin{array}{c}\text { Removal (\%) } \\
\text { after 30 mins }\end{array}$ & $\begin{array}{c}\mathrm{C}(\mathrm{ppm}) \\
\text { after 60 min }\end{array}$ & $\begin{array}{c}\text { Removal (\%) } \\
\text { after } 60 \text { mins }\end{array}$ \\
\hline $\mathrm{Cd}$ (II) & 0.27 & 94.6 & 0.04 & 99.2 \\
$\mathrm{Cr}$ (III) & 0.33 & 93.4 & 0.001 & 99.7 \\
$\mathrm{Sr}$ (II) & 0.03 & 99.4 & 0.009 & 99.8 \\
$\mathrm{Ca}$ (II) & 0.72 & 85.6 & 0.13 & 97.3 \\
$\mathrm{Au}$ (III) & 3.12 & 37.6 & 3.38 & 42.4 \\
$\mathrm{Hg}$ (II) & 0.02 & 98.5 & 0.02 & 99.4 \\
$\mathrm{~Pb}$ (II) & 0.40 & 92.02 & 0.05 & 99.1 \\
$\mathrm{As}$ (V) & 1.37 & 72.6 & 0.02 & 99.6 \\
\hline
\end{tabular}

is able to adsorb $\mathrm{Sr}, \mathrm{Cr}, \mathrm{As}, \mathrm{Hg}, \mathrm{Cd}, \mathrm{Pb}$, and $\mathrm{Ca}$ ions through a physico-chemical process and remove them from drinking water with high removal rates (\%) of 99.8, 99.7, 99.6, 99.4, 99.2, 99.1, and 97.3, respectively. According to Table 3, this natural surfactant has less affinity to bind with gold ions in comparison with other metals examined. It shows a moderate removal rate of $42.4 \%$. Gold ions were used in the form of $\mathrm{AuCl}_{4}{ }^{-}$ions.

We have also found ${ }^{12}$ that the ion flotation system using S-octanoyl-cys surfactant at an initial concentration of $0.01 \mathrm{M}$ and at $\mathrm{pH} 8$, can successfully remove copper ions at $50 \mathrm{mg} / \mathrm{L}$ in aqueous solutions. The results show a high removal rate for copper ions using this surfactant and in the hydrated form of copper ions, in the sulphate salt, even visual observation shows a noticeable visible blue colour at concentrations higher than about $200 \mathrm{mg} / \mathrm{L}$ of $\mathrm{Cu}^{2+}$. The results observed for ion flotation of copper ions at $500 \mathrm{mg} / \mathrm{L}$ indicates that using the S-octanoyl-cys causes this colour to rapidly disappear, which confirms that the ion-flotation process should be directed towards the development of novel treatment methods for the removal of heavy-metal ions, such as $\mathrm{Cu}$, from mining wastewater.

\subsection{Selectivity in mixtures of ions}

Extending these results, we have illustrated the removal efficiency and the selectivity of S-octanoyl-cys to remove several ions in a mixed aqueous solution with initial concentrations of $5 \mathrm{mg} / \mathrm{L} .{ }^{12}$ These experiments were undertaken in the presence of an initial concentration of $0.01 \mathrm{M}$ of the surfactant and $\mathrm{pH}=8$. After 60 minutes samples were taken. Although this green surfactant showed excellent removal rates for single metal ions in aqueous solution, after ICP-MS analysis for a

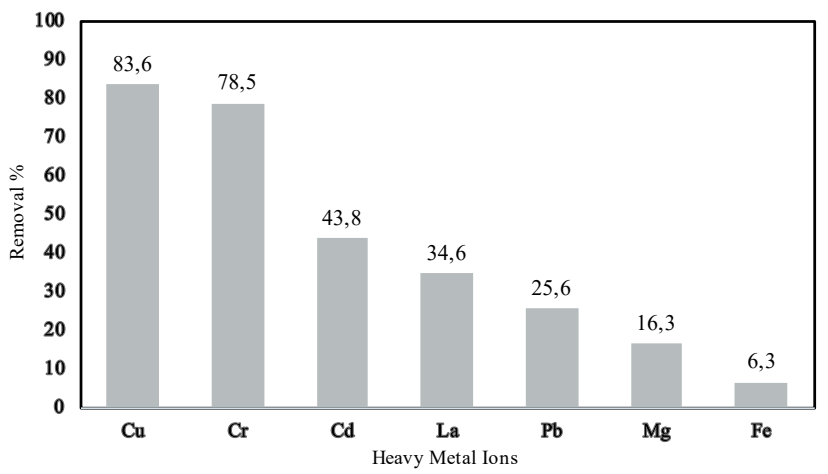

Figure 3. Removal rate of different heavy-metal ions in a mixed aqueous solution using S-octanoyl-cysteine surfactant through a batch stage ion flotation process (Reprinted from Ref. 12, with permission from Elsevier). 
mixture of metal ions, the results indicated that some of the metal ions were clearly bound more strongly. The removal rate results for an aqueous solution containing seven heavy-metal ions $(\mathrm{Cu}, \mathrm{Cr}, \mathrm{Cd}, \mathrm{La}, \mathrm{Pb}, \mathrm{Mg}$, and $\mathrm{Fe})$ are depicted in Figure 3.

Based on the data from ICP-MS analysis, copper and chromium ions also show strong binding affinity to the surfactant with removal rates of $83 \%$ and $78 \%$, respectively. However, in comparison with other heavy-metal ions, iron and magnesium ions exhibited less bonding. The removal rates were $16 \%$ and $6 \%$ for $\mathrm{Mg}$ and $\mathrm{Fe}$ ions, respectively.

\subsection{Other applications}

In addition to removal of pollutants from water, there is another significant application for ion flotation. This technique has found its way as a promising separation process with especial interest in heavy metal ions recovery. Therefore, further research on the effectiveness of the green S-octanoyl-cys surfactant has been conducted for separation of iron and lanthanum ions in an aqueous solution. For this purpose, a mixed solution of $5 \mathrm{mg} / \mathrm{L}$ of lanthanum and iron ions was studied and ion flotation was undertaken using an initial concentration of $0.01 \mathrm{M}$ of s-octanoyl-cys surfactant at $\mathrm{pH}=8$. After 60 minutes bubbling, samples of solution remaining in the column were taken and the results are reported in Table 4.

It is evident that besides excellent heavy metal removal capacity of this surfactant, it also can be used to separate or produce specific recovery of some metal ions from a mixed aqueous solution. The Table indicates S-octanoyl-cys surfactant has a stronger binding affinity with lanthanum ions rather than iron ions. As a result, La recovery is almost 12 times more than Fe removal.

\section{CHEMICAL SYNTHETIC SURFACTANTS}

Chemical synthetic surfactants were initially used by $\mathrm{Sebba}^{23}$ in a flotation process to concentrate inorganic

Table 4. Flotation results for a mixed solution of iron and lanthanum, using s-octanoyl-cys surfactant in a batch process. Initial concentration of $\mathrm{La}$ and $\mathrm{Fe}$ are $5 \mathrm{mg} / \mathrm{L}$. Initial surfactant concentration $=0.01 \mathrm{M}$ and $\mathrm{pH}=8$. $\left(\right.$ Reproduced from $\left.{ }^{12}\right)$.

\begin{tabular}{ccccc}
\hline Mixed Ions & $\begin{array}{c}\mathrm{C}(\mathrm{mg} / \mathrm{L}) \\
\text { after 30 min }\end{array}$ & $\begin{array}{c}\text { Removal (\%) } \\
\text { after 30 min }\end{array}$ & $\begin{array}{c}\mathrm{C}(\mathrm{mg} / \mathrm{L}) \\
\text { after 60 min }\end{array}$ & $\begin{array}{c}\text { Removal (\%) } \\
\text { after 60 min }\end{array}$ \\
\hline Iron & 4.78 & 4.4 & 4.6 & 8.0 \\
Lanthanum & 1.00 & 80 & 0.27 & 94.6 \\
\hline
\end{tabular}

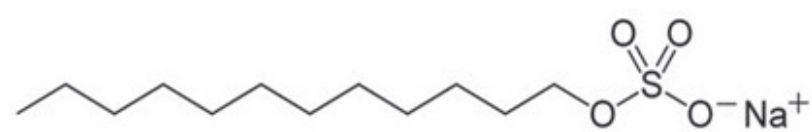

Figure 4. The molecular structure of sodium dodecyl sulfate (SDS) as an anionic chemical synthetic surfactant. ${ }^{34}$

ions from aqueous solutions. This type of surfactant is widely used in industry since the molecular structures could be designed as they are required. Alkane sulfonate, alkylamine, disodiumalkyl malonate, xanthate, sodium oleate, and sodium dodecyl sulfate (SDS) have been widely applied in ion flotation. ${ }^{24}$ Besides the advantage of using chemical synthetic surfactants, there are a number of drawbacks to applying them in industry.

Chemical synthetic surfactants demonstrate considerable biological activity. For instance, anionic chemical synthetic surfactants are able to form bonds with macromolecules such as enzymes, peptides, and DNA which might alter their surface charge and vary the folding of the polypeptide chain. This binding can interfere their normal biological functions. ${ }^{25,26}$

Furthermore, quaternary ammonium compounds are the most common type of cationic surfactants. They are known to bind with the inner membrane of bacteria. As a result, this type of chemical synthetic surfactant can disorganise them and affect their normal functions ${ }^{27-32}$ cationic surfactants are potent immunosuppressants, a fact as widely known as it is ignored.

The fact that our cysteine-based surfactants are not toxic and actually edible is highly significant. In addition, non-ionic surfactants demonstrate the ability of binding with phospholipid membranes and different proteins. This binding raises permeability of cellular membranes which can cause cell damage or death due to loss of amino acids and ions. ${ }^{33}$

It is notable that sodium dodecyl sulfate (SDS) is one of the most well-known chemical synthetic surfactant that is used widely in industries. This surfactant is also known as sodium lauryl sulfate. Figure 4 illustrates the molecular structure of this anionic surfactant.

The effectiveness this surfactant in removing heavymetal ions has been assessed in a number of reports. For example, Yenidünya ${ }^{34}$ applied SDS as the collector in an ion flotation process for removing $\mathrm{Mn}^{2+}, \mathrm{Cu}^{2+}$, and $\mathrm{Zn}^{2+}$ from water. After 60 minutes flotation, $99.8 \%$, $90.5 \%$, and $73.4 \%$ of magnesium, copper, and zinc were removed from the aqueous solution. Table 5 shows the results obtained from various studies using SDS for removal of heavy-metal ions through ion flotation. According to Table 5, although a frother and axillary ligand have been used, the achieved removal rates are 
Table 5. Using sodium dodecyl sulfate and tea saponin surfactants in the process of ion flotation for removing heavy metal ions from water.

\begin{tabular}{|c|c|c|c|c|}
\hline Surfactant & Pollutants & Condition & Removal (\%) & Ref. \\
\hline Sodium Dodecyl Sulphate (SDS) & $\mathrm{Zn}$ (II), Mn (II), Cu (II) & $\mathrm{C}_{\text {metal }}: \mathrm{C}_{\mathrm{SDS}}: \mathrm{C}_{\text {axillary ligand }}=1: 5: 5, \mathrm{pH}=4$ & $90.5,99.8,73.4$ & 35 \\
\hline Sodium Dodecyl Sulphate (SDS) & $\mathrm{Cr}(\mathrm{III})$ & $\mathrm{C}_{\mathrm{SDS}}: \mathrm{C}_{\text {metal }}=2, \mathrm{pH}=8$ & 91.6 & 36 \\
\hline Sodium Dodecyl Sulphate (SDS) & $\begin{array}{c}\mathrm{Cu}(\mathrm{II}), \mathrm{Pb}(\mathrm{II}), \mathrm{Ni}(\mathrm{II}) \\
\mathrm{Cd}(\mathrm{II}), \mathrm{Zn}(\mathrm{II})\end{array}$ & $\mathrm{C}_{\text {metal }}: \mathrm{C}_{\mathrm{SDS}}=1, \mathrm{pH}=9$ & $\begin{array}{c}97.5,87.5,87,83 \\
92.5\end{array}$ & 37 \\
\hline Sodium Dodecyl Sulphate (SDS) & $\mathrm{Cd}(\mathrm{II})$ & $\mathrm{C}_{\mathrm{SDS}}: \mathrm{C}_{\mathrm{Cd}}=3, \mathrm{pH}=4$ & 94 & 38 \\
\hline Sodium Dodecyl Sulphate (SDS) & $\mathrm{Ni}$ (II), Zn (II) & $\mathrm{C}_{\mathrm{SDS}}: \mathrm{C}_{\text {metal }}=13.5, \mathrm{pH}=9.7$ & $99.8,90.4$ & 39 \\
\hline Sodium Dodecyl Sulphate (SDS) & Cd (II) & $\mathrm{C}_{\mathrm{SDS}}: \mathrm{C}_{\text {metal }}=2, \mathrm{pH}=10$ & 99.8 & 38 \\
\hline Tea Saponin & $\mathrm{Cu}(\mathrm{II})$ & $\mathrm{C}_{\text {surfactant }}: \mathrm{C}_{\text {metal }}=3, \mathrm{pH}=4$ & 81 & 40 \\
\hline Tea Saponin & Cd (II) & $\mathrm{C}_{\text {surfactant }}: \mathrm{C}_{\text {metal }}=11, \mathrm{pH}=7.5$ & 8 & 41 \\
\hline Tea Saponin & $\mathrm{Pb}(\mathrm{II})$ & $\mathrm{C}_{\text {surfactant }}: \mathrm{C}_{\text {metal }}=11, \mathrm{pH}=4.8$ & 12 & 41 \\
\hline
\end{tabular}

relatively lower than those obtained by S-octanoyl-cys surfactant.

Tea saponin is uncharged with a CMC value of about $0.72 \mathrm{mM} .{ }^{33}$ In a recent study, ${ }^{34}$ tea saponin was used for removing cadmium, lead and copper ions in aqueous solutions. The highest efficiencies were achieved when the tea saponin ratio to heavy metal was $3: 1$ at $\mathrm{pH}=6$. The removal efficiency decreased slightly with increasing in ionic strength obtained by adding $\mathrm{NaCl}$ solutions (in the range 0.001-0.004 M).

\section{BIOSURFACTANT}

Biosurfactants are known as ecosystem friendly compounds, which are found in plants, animals, and microbes etc. Most biosurfactants are found either in anionic or non-ionic form and only a few of them are cationic. ${ }^{42,43}$ The lipophilic part of these biosurfactants

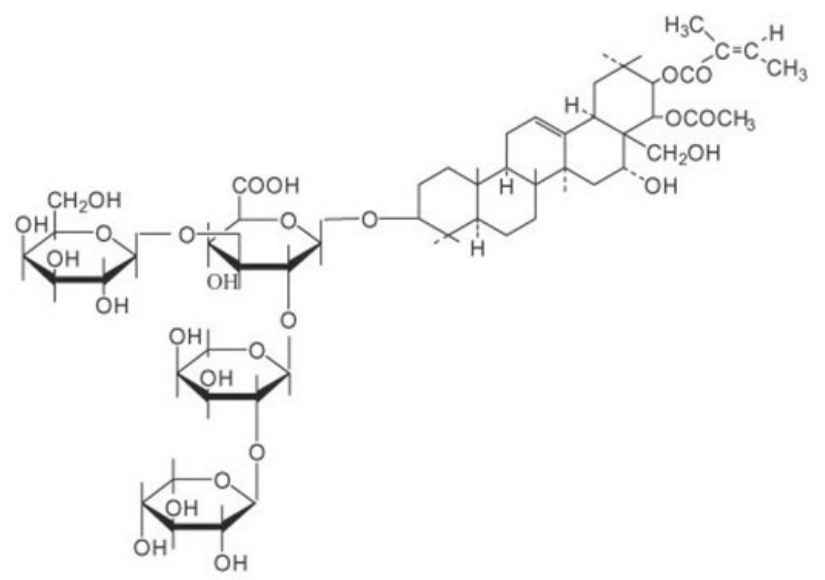

Figure 5. The molecular structure of tea saponin molecule as an example of a non-ionic biosurfactant. ${ }^{47}$ is usually based on long-chain fatty acids. ${ }^{4}$ The hydrophilic sector can be an amino acid, cyclic peptide, carbohydrate, alcohol, or carboxylic acid. ${ }^{45}$ Biosurfactants are widely applied as additives in food industry, adsorbents for environmental treatment, and flocculants because of their properties such as biodegradability, low toxicity, and biocompatibility. ${ }^{46}$ Due to stricter environmental regulations, biosurfactants would be the promising alternatives to the traditional chemical synthetic surfactants.

The tea saponin molecule, found in Camellia plants, is a non-ionic surfactant which has been used in soil and water treatments. ${ }^{47}$ The molecular structure of this surfactant is depicted in Figure 5.

A very small number of studies have been conducted to ascertain the effectiveness of heavy metal ion removal using tea saponin biosurfactant in the ion flotation technique. Table 5 shows the results obtained for heavy metal removal from water using tea saponin as the collector in an ion flotation process. The removal rates of $\mathrm{Cu}^{2+}$, $\mathrm{Cd}^{2+}$, and $\mathrm{Pb}^{2+}$ from water using this surfactant were found to be $81 \%, 8 \%$, and $12 \%$, respectively. Although tea saponin is a relatively ecosystem friendly biosurfactant, it does not show a satisfactory removal rate for cadmium and lead ions. It is notable that long flotation times and low removal efficiency are the main limits of applying biosurfactants in large-scale water treatment plants. Therefore, more research is required on developing biosurfactants to make them of greater practical value in the water treatment industry.

\section{SUMMARY}

The Na-octanoyl amino acid-based single-chain cysteine surfactant shows a high-water solubility and high foaming ability over a wide $\mathrm{pH}$ range. In a batch ion flotation process, this surfactant was able to remove 
97-99\% of the initial $5 \mathrm{ppm}$ level of strontium, lanthanum, arsenic and different heavy metal ions at levels typically present in contaminated water, in a simple, single-stage physiochemical process. The surfactant showed significantly lower efficiency for the removal of iron, selenium and gold ions. In a solution mixed with heavy-metal ions, including arsenic, copper, cadmium, magnesium, lanthanum, chromium, lead and iron, the surfactant shows a higher affinity to bind with arsenic, copper and chromium compared with the others. Moreover, the effectiveness of this surfactant for removal of gold ions from aqueous binary mixtures in the presence of iron and mercury ions has been explored. This new surfactant is highly efficient compared with commercial surfactants (e.g., SDS and CTAB) for ion flotation. Importantly, it is also an environmentally acceptable compound. It can be decomposed into cysteine (amino acid) and octanoic acid (caprylic acid), which is taken as a dietary supplement. The surfactant has the potential for wide usage in ion flotation and in froth flotation. ${ }^{48}$

In the ion flotation experiments reported here, the cysteine surfactant concentration was in the range 10 $\mathrm{mM}$ (initially) to $5 \mathrm{mM}$, whereas the initial metal ion concentrations were in the range: $0.1 \mathrm{mM}$ (for light elements ions such as $\mathrm{Ca}$ ) and $0.025 \mathrm{mM}$ (for the heavy elements, $\mathrm{Au}, \mathrm{Hg}$ and $\mathrm{Pb}$ ). Hence, in all cases, the surfactant was always present in the batch column process in excess, relative to the metal ion concentrations.

It should be noted that in this protocol the surfactant, unlike the ions, was not fully depleted from the column during 60 minutes of bubbling time. That is, the surfactant concentration was approximately halved in the column during the bubbling experiments. Hence, the surfactant was always present in the column at a much higher concentration level than the metal ions, during these experiments. These conditions were used to illustrate the relative selectivity of the surfactant for a range of different ions, as shown in the results, from a series of single and mixed ion flotation experiments presented here.

By comparison, in a commercial process much longer ion flotation columns would be used to increase the efficiency of ion collection relative to the surfactant concentration, since the surfactant coated rising bubbles will continue to remove ions from the solution until they have reached saturated adsorption densities.

\section{CONCLUSIONS AND FUTURE PROSPECTS}

We have shown that ion flotation can be used for the treatment of contaminated waters containing toxic metallic ions. The example given is that of the $S$-octanoyl-cys surfactant, which can remove a range of low level toxic ions from water. The significant selectivity of this surfactant for some of the ions studied is also most encouraging. It suggests that the ion flotation process could be used to completely separate some specific ion mixtures that pose problems, like rare earth ions. More research and methodological work is needed on how to harvest other valuable ions, such as gold, to reduce the significant costs of current refining processes. The surfactant also showed high efficiency for the removal of relatively high concentrations of copper ions, which could be used as a promising alternative for the treatment of different industrial and mining wastewater.

From a sustainability view-point, the surfactant collected in the foam can be released from the bound ion and then re-used to enable recycling of the surfactant. This surfactant also readily decomposes into products which are acceptable for human ingestion. It is also worth mentioning that the commercial development of this process would have a wide variety of applications and can address the global issue of heavy metal ion presence in drinking water.

A final observation: many enzymes have an active site, a hydrophobic pocket, centred around a specific ion which is generally divalent. The binding is highly specific and the ion sets the required structure of the hydrophobic pocket that allows the enzyme-substrate lock and key process. For example, with the restriction enzyme Hindi 2, the specific ion, e.g magnesium, can be replaced by suboptimal calcium, manganese, copper or nickel. ${ }^{48}$ With the suboptimal replacements, the enzyme can still "work", but not so efficiently and the chain of subsequent reactions is affected. This explains why trace elements are necessary, for both plants and animals, and why small amounts of ions like arsenic are so toxic. That different enzymes bind different trace ions so selectively may provide an entry into a wide range of other novel surfactants.

\section{ACKNOWLEDGMENTS}

The authors would like to gratefully acknowledge Ms. Rabeya Akter for ICP-MS analysis support within the Mark Wainwright Analytical at the University of New South Wales. The authors also thank Dr Fatemeh Makavipour for her assistance with the arsenic flotation experiments. The author M.Z. acknowledges UNSW Canberra to provide postgraduate research scholarship. 


\section{REFERENCES}

1. I.Y. El-Sherif, S. Tolani, K. Ofosu, O.A. Mohamed, A.K. Wanekaya, Polymeric nanofibers for the removal of $\mathrm{Cr}$ (III) from tannery waste water, J. Environ. Manage., 2013, 129, 410-413.

2. K. Fischer, H.-P. Bipp, Removal of Heavy Metals from Soil Components and Soils by Natural Chelating Agents. Part II. Soil Extraction by Sugar Acids, Water, Air, Soil Pollut., 2002, 138, 271-288.

3. C. Mohanna, Y. Nys, Effect of dietary zinc content and sources on the growth, body zinc deposition and retention, zinc excretion and immune response in chickens, British Poultry Science, 1999, 40, 108-114.

4. WHO, Copper in drinking-water, in, WHO, 2004.

5. WHO, Mercury in Drinking-water, in: Background document for development of WHO Guidelines for Drinking-water Quality, 2005.

6. Z. Yu, X. Zhang, Y. Huang, Magnetic ChitosanIron(III) Hydrogel as a Fast and Reusable Adsorbent for Chromium(VI) Removal, Ind. Eng. Chem. Res., 2013, 52, 11956-11966.

7. D. Ko, J.S. Lee, H.A. Patel, M.H. Jakobsen, Y. Hwang, C.T. Yavuz, H.C.B. Hansen, H.R. Andersen, Selective removal of heavy metal ions by disulfide linked polymer networks, J. Hazard. Mater., 2017, 332, 140-148.

8. C.K. Jain, I. Ali, Arsenic: Occurrence, toxicity and speciation techniques, Water Res., 2000, 34, 43044312.

9. P.L. Smedley, D.G. Kinniburgh, A review of the source, behaviour and distribution of arsenic in natural waters, Appl. Geochem., 2002, 17, 517-568.

10. M.J. Rosen, J.T. Kunjappu, Micelle Formation by Surfactants, in: Surfactants and Interfacial Phenomena, John Wiley \& Sons, Inc., 2012, 123-201.

11. H. Polat, D. Erdogan, Heavy metal removal from waste waters by ion flotation, J. Hazard. Mater., 2007, 148, 267-273.

12. M. Taseidifar, M. Ziaee, R.M. Pashley, B.W. Ninham, Ion flotation removal of a range of contaminant ions from drinking water, J. Environ. Chem. Eng., 2019, 7(4), 103263.

13. S. Rebello, A.K. Asok, S. Mundayoor, M.S. Jisha, Surfactants: toxicity, remediation and green surfactants, Environ. Chem. Lett., 2014, 12, 275-287.

14. S. Shen, X.-F. Li, W.R. Cullen, M. Weinfeld, X.C. Le, Arsenic binding to proteins, Chem. Rev., 2013, 113, 7769-7792.

15. M. Taseidifar, F. Makavipour, R.M. Pashley, A.F.M.M. Rahman, Removal of heavy metal ions from water using ion flotation, Environ. Technol. Innov., 2017, 8, 182-190.
16. M. Taseidifar, Environmental applications of a biodegradable cysteine-based surfactant, Ecotoxicol. Environ. Saf., 2020, 206, 111389.

17. B.T. Farrer, C.P. McClure, J.E. Penner-Hahn, V.L. Pecoraro, Arsenic(III)-Cysteine Interactions Stabilize Three-Helix Bundles in Aqueous Solution, Inorg. Chem., 2000, 39, 5422-5423.

18. M.C. Teixeira, V.S.T. Ciminelli, M.S.S. Dantas, S.F. Diniz, H.A. Duarte, Raman spectroscopy and DFT calculations of As(III) complexation with a cysteine-rich biomaterial, J. Colloid Interface Sci., 2000, 315, 128-134.

19. C. Baumann, A. Beil, S. Jurt, M. Niederwanger, O. Palacios, M. Capdevila, S. Atrian, R. Dallinger, O. Zerbe, Structural Adaptation of a Protein to Increased Metal Stress: NMR Structure of a Marine Snail Metallothionein with an Additional Domain, Angew. Chem. Int. Ed., 2017, 56, 4617-4622.

20. F. Makavipour, R.M. Pashley, A.F.M.M. Rahman, Low-Level Arsenic Removal from Drinking Water, Global Challenges, 2019, 3(3), 1700047.

21. J.F. Ferguson, J. Gavis, A review of the arsenic cycle in natural waters, Water Res., 1972, 6, 1259-1274.

22. B. Maher, Measuring arsenic in rice - an Australian reference material, Royal Australian Chemical Institute, 2015, pp. 38.

23. F. Sebba, Concentration by Ion Flotation, Nature, 1959, 184, 1062-1063.

24. L.-C. Shen, X.-T. Nguyen, N.P. Hankins, Removal of heavy metal ions from dilute aqueous solutions by polymer-surfactant aggregates: A novel effluent treatment process, Sep. Purif. Technol., 2015, 152, 101107.

25. T. Cserhati, E. Forgács, G. Oros, Biological activity and environmental impact of anionic surfactants, Environ. Int., 2002, 28, 337-348.

26. R. Waninge, M. Paulsson, T. Nylander, B. Ninham, P. Sellers, Binding of Sodium Dodecyl Sulphate and Dodecyl Trimethyl Ammonium Chloride to $\beta$-Lactoglobulin: A Calorimetric Study, Int. Dairy J., 1998, 8, 141-148.

27. G. McDonnell, A.D. Russell, Antiseptics and Disinfectants: Activity, Action, and Resistance, Clin. Microbiol. Rev., 1999, 12, 147-179.

28. R.B. Ashman, B.W. Ninham, Immunosuppressive effects of cationic vesicles, Mol. Immunol., 1985, 22, 609-612.

29. R.B. Ashman, R.V. Blanden, B.W. Ninham, D.F. Evans, Interaction of amphiphilic aggregates with cells of the immune system, Immunol. Today, 1986, 7, 278-283.

30. P. Lo Nostro, B.W. Ninham, A. Lo Nostro, G. Pesavento, L. Fratoni, P. Baglioni, Specific ion effects 
on the growth rates of Staphylococcus aureus and Pseudomonas aeruginosa, Phy. Biol., 1986, 2, 1-7.

31. B.W. Ninham, K. Larsson, P. Lo Nostro, Two sides of the coin. Part 1. Lipid and surfactant self-assembly revisited, Colloids Surf. B: Biointerfaces, 2017, 152, 326-338.

32. B.W. Ninham, K. Larsson, P. Lo Nostro, Two sides of the coin. Part 2. Colloid and surface science meets real biointerfaces, Colloids Surf. B: Biointerfaces, 2017, 159, 394-404.

33. T. Cserhati, Alkyl Ethoxylated and Alkylphenol Ethoxylated Nonionic Surfactants: Interaction with Bioactive Compounds and Biological Effects, Environ. Health Perspect., 1995, 103, 358-364.

34. L. Chang, Y. Cao, G. Fan, C. Li, W. Peng, A review of the applications of ion floatation: wastewater treatment, mineral beneficiation and hydrometallurgy, RSC Adv., 2019, 9, 20226-20239.

35. X.-L. Yu, Y. He, Development of a Rapid and Simple Method for Preparing Tea-Leaf Saponins and Investigation on Their Surface Tension Differences Compared with Tea-Seed Saponins, Molecules, 2018, 23(7), 1796.

36. X.Z. Yuan, Y.T. Meng, G.M. Zeng, Y.Y. Fang, J.G. Shi, Evaluation of tea-derived biosurfactant on removing heavy metal ions from dilute wastewater by ion flotation, Colloids Surf., A:Physiochem. Eng. Aspects, 2008, 317, 256-261.

37. M. Doğutan Yenidünya, Recovery of $\mathrm{Zn}(\mathrm{II}), \mathrm{Mn}$ (II) and $\mathrm{Cu}(\mathrm{II})$ in Aqueous Solutions by Foam Fractionation with Sodium Dodecyl Sulphate in Combination with Chelating Agents, Sep. Sci. Technol., 2006, 41, 1741-1756.

38. V.S.H. Khoshdast, Efficient chromium removal from aqueous solutions by precipitate flotation using rhamnolipid biosurfactants, Physicochem. Probl. Miner. Process., 2018, 54, 1014-1025.

39. Ü. Yenial, G. Bulut, Examination of flotation behavior of metal ions for process water remediation, J. Mol. Liq., 2017, 241, 130-135.

40. A.I. Zouboulis, K.A. Maris, Removal of cadmium from dilute solutions by flotation, Water Sci. Technol., 1995, 31, 315-326.

41. F.S. Hoseinian, M. Irannajad, A.J. Nooshabadi, Ion flotation for removal of $\mathrm{Ni}(\mathrm{II})$ and $\mathrm{Zn}$ (II) ions from wastewaters, Int. J. Miner. Process., 2015, 143, 131-137.

42. T. Pekdemir, S. Tokunaga, Y. Ishigami, K.-J. Hong, Removal of cadmium or lead from polluted water by biological amphiphiles, J Surfactants Deterg., 2000, 3, 43-46.

43. J. Tang, J. He, X. Xin, H. Hu, T. Liu, Biosurfactants enhanced heavy metals removal from sludge in the electrokinetic treatment, Chem. Eng. J., 2018, 334, 2579-2592.

44. S. Shekhar, A. Sundaramanickam, T. Balasubramanian, Biosurfactant Producing Microbes and their Potential Applications: A Review, Crit. Rev. Environ. Sci. Technol., 2015, 45, 1522-1554.

45. E.Z. Ron, E. Rosenberg, Natural roles of biosurfactants, Environ. Microbiol., 2001, 3, 229-236.

46. C.N. Mulligan, Recent advances in the environmental applications of biosurfactants, Curr. Opin. Colloid Interface Sci., 2009, 14, 372-378.

47. R. Cohen, D. Exerowa, Surface forces and properties of foam films from rhamnolipid biosurfactants, $A d v$. Colloid Interface Sci., 2007, 134-135, 24-34.

48. M. Taseidifar, A.G. Sanchis, R.M. Pashley, B.W. Ninham, Novel water treatment processes, Substantia, 2019, 3(2), 11-17.

49. H. K. Kim, E. Tuite, B. Nordén, B. W. Ninham, Coion dependence of DNA nuclease activity suggests hydrophobic cavitation as a potential source of activation energy, Eur. Phys. J., 2001, 4, 411-417. 